\title{
SUSTAINABLE MANAGEMENT POLICY STRATEGY OF COASTAL TOURISM IN PANGANDARAN DISTRICT, INDONESIA
}

\author{
Achmad RIZAL \\ Universitas Padjadjaran, Faculty of Fisheries and Marine Science, West Java, Indonesia, e-mail: achmad.rizal@unpad.ac.id \\ Izza M. APRILIANI \\ Universitas Padjadjaran, Faculty of Fisheries and Marine Science, West Java, Indonesia, e-mail: izza.mahdiana@unpad.ac.id \\ Rega PERMANA \\ Universitas Padjadjaran, Faculty of Fisheries and Marine Science, West Java, Indonesia, e-mail: rega.permana@unpad.ac.id
}

\begin{abstract}
Citation: Rizal, A., Apriliani, I.M., \& Permana, R. (2021). SUSTAINABLE MANAGEMENT POLICY STRATEGY OF COASTAL TOURISM IN PANGANDARAN DISTRICT, INDONESIA. GeoJournal of Tourism and Geosites, 37(3), $894-904$. https://doi.org/10.30892/gtg.37321-723
\end{abstract}

\begin{abstract}
One of the crucial coastal tourism is a region of Pangandaran District coastal tourism. The area represented a coastal region that has various exploiting characteristics and interconnected one another. The primary purpose of this research is to analyze the sustainable management policy strategy of coastal tourism. To reach the especial target, hence there are so me activities which require to be conducted as a particular target that is (1) identifying determinant in the future, (2) determining strategic target and importance of the main stakeholder; and (3) defining and describe of evolution possibility of future. The prospective analysis was conducted to yield a sustainable regional development scenario of coastal tourism in Pangandaran District, with determining key factors that affect system performance. From various possibilities that could happen, is formulated three regional development scenario of Pangandaran District coastal tourism to come, that are : 1) Conservative Pessimistic by conducting to repair of main key factor only, 2) Moderate - Optimistic by conducting repair about $50 \%$ of the primary key attribute (factor), 3) Progressive - Optimistic by conducting repair to entire key attribute (factor). To increase sustainable status forwards (long-period), a scenario that must be conducted to increase the regional sustainable development status of the coastal of Pangandaran District is Progressive - Optimistic by conducting repair by totally to all sensitive attribute so that all dimension become sustainable for coastal region development.
\end{abstract}

Key words: Pangandaran District, Coastal Tourism, Sustainable Management, Policy Strategy

\section{INTRODUCTION}

Coastal tourism is a process involving tourists and the people and places they visit. It is more specifically defined as tourism brought to bear on the coastal environment and its natural and cultural resources. Most coastal zone tourism takes place along the shore and in the water immediately adjacent to the shoreline. Coastal tourism activities occur outdoors and indoors as recreation, sport, play, leisure, and business (Miller and Ditton, 1986; Miller and Hadley, 2005). One of the coastal tourism that is economically and ecologically important in West Java Province is coastal tourism in Pangandaran District. Pangandaran coastal tourism is established nationally as a tourism destination. Pangandaran tourism is coastal tourism with various uses and is related to one another. In the Pangandaran district, there are economic activities based on natural resources such as capture fisheries, housing, transportation, and coastal tourism itself. Pangandaran has also become a National Tourism Strategic Area (NTSA), an area with the primary function of tourism or can develop national tourism, which has a significant influence Pangandaran is one of the top attractions in West Java Province.

The existence of various activities in the coastal environment of Pangandaran District has led to a decrease in environmental quality in the form of pollution and changes in coastal morphology. Based on the results of research by Permana et al. (2020), the cause of the decline in the quality of the coastal environment of Pangandaran District is thought to have come from three dominant sources, namely the concentration of population in the capital city of Pangandaran, industrial activities, and agricultural activities in the upper reaches of the Cikidang river and Cikembulan river. The concentrated urban population produces a large amount of solid and liquid waste (Rizal et al., 2019). The waste enters the Pangandaran coastal waters and results in silting the coast and changes in water quality parameters such as DO (Dissolved Oxygen / Oxygen Demand) content, BOD (Biological Oxygen Demand) value, COD (Chemical Oxygen Demand) value, and the appearance of toxic and eutrophied compounds. With these various kinds of problems, efforts are needed to manage coastal tourism in Pangandaran District in a sustainable manner so that Pangandaran District's distinctive features as a "Coastal tourism City" will be maintained. This management cannot be separated from three leading environmental management indicators: economic, social, and environmental benefits. Efforts to minimize the negative impact of coastal tourism management and maintain the ecosystem's stability can be made by compiling an environmentally sound 
management plan so that the area's arrangement can be more optimal and does not exceed its carrying capacity. In the context of optimal and sustainable coastal management, an integrated management policy direction is required (Moreno and Amelung, 2009; Palmer, 2012; Rizal et al., 2020a; Rizal et al., 2020b).

Pangandaran is a Coastal tourism City that is very vulnerable to various changes, but these changes are expected to continue to pay attention to environmental aspects because it is a complex and dynamic ecosystem. For this reason, a sustainable coastal tourism management policy strategy in Pangandaran District is essential so that the effects of tourism on the coastal environment can be known and anticipated. The main objective of this research is to analyze the strategy for sustainable coastal tourism management policies. Several activities need to be carried out to achieve the main objectives, as specific objectives, namely (1) identifying future determinants, (2) determining the strategic objectives and interests of the main actors, and (3) define and describe the possible evolution of the future.

\section{LITERATUR REVIEW AND METHODS}

Tourism Assessment and Future Challenges

Although the exact beginnings of the phrase "tourism academics" are difficult to trace, it is generally assumed that tourism research has experienced rapid development in the last two decades. Butler (2015) points out that it is a common misconception that tourism emerged after the advent of mass tourism, while recent travel has a lot in common with tourism dating back two thousand years. Travel literature itself does have a millennial history with early evidence of travel writings by the ancient Greeks and Romans. Tourism is defined as a multidisciplinary field, the interest of tourism academics has grown steadily, and the number of journals has increased significantly. However, at the technical level in the field, it has long been criticized because tourism studies are considered to have limited capacity to solve real-world problems (Wagner et al., 2011; Butler, 2015; Mostafa and Mahmood, 2018; Zenker and Kock, 2020).

Contemporary tourism academics find their roots in early descriptive and advocacy studies of tourism phenomena (Wagner et al., 2011; Butler, 2015; Zenker and Kock, 2020), while a more cautious and critical turn was initiated in part by intense theoretical developments in the 1970s; primarily as responding to real-world and industrial problems. Regarding current tourism academics, a complex picture of a multidisciplinary field that is developing globally. Tourism researchers are now facing a situation called the phenomenon of uncertain evolution of the future related to sustainable tourism opportunities. The situation of possible future evolution is an unexpected phenomenon in the modern history of tourism. Several management experts have reviewed that this will be an essential issue for tourism studies to assist research efforts during the pandemic crisis (Wagner et al., 2011; Butler, 2015; Zenker and Kock, 2020).

\section{Tourism Development Policy}

Tourism policy is a product of a very complex process and is related to various aspects. The complexity of tourism is caused by significant changes at the local, national, and international levels. In the context of this significant change, the policy environment on tourism has become a strategic medium for the government to market its tourism potential (UNWTO, 2005; Rizal et al., 2019; Trip et al., 2021). In this condition, tourism policy becomes very strategic and essential in tourism development. Tourism is a multidimensional and cross-sectoral industry (Panzabekova, 2018; Trip et al., 2021). The involvement of all parties is needed because tourism is not an independent sector. The consideration of the linkages between sectors and the handling of tourism is increasingly complicated in developing an integrated destination.

One of the stakeholders that has an important role is a good understanding of the government in planning and implementing all tourism planning consistently and sustainably. The government will certainly pay attention and ensure that tourism development will benefit while reducing social, economic, and environmental impacts. On the other hand, more profit-oriented business actors cannot regulate what to do, but the government can regulate what they cannot do through policies and regulations, for example, by establishing spatial regulations, permits, licenses, accreditation, and legislation (Miller and Ditton, 1986; Miller and Hadley, 2005; Moreno and Amelung, 2009; Palmer, 2012).

Government intervention in tourism development can be carried out by implementing several policy instruments. That can be used to control and provide incentives in developing sustainable tourism, such as; land use regulations, limiting tourist access to areas prone to damage, protecting local culture, directing environmentally friendly tourist behavior, limiting energy use, conserving scarce natural resources, reducing pollution and providing incentives to infrastructure development that also benefits hosts such as transportation systems, protection of urban green spaces and national parks (Pahl-Wostl et al., 2013; Lemmetyinen, 2017; Leposa, 2020; Aktymbayeva et al., 2020). The choice of a policy instrument will be very decisive if it is based on a comprehensive study of the objectives to be achieved in the most efficient manner possible, not based on a partial and incomplete study. The most important thing also needs to be based on good morals and political will. Currently, developing issues regarding tourism planning emphasize the technical aspects, even though it is a political problem concerning the regulation of all existing tourism components in the direction of sustainable tourism (Lemmetyinen, 2017; Panzabekova, 2018; Leposa, 2020; Aktymbayeva et al., 2020; Trip et al., 2021).

The role of policymakers is critical in determining tourism policies that will be taken to develop sustainable tourism. For this reason, it is necessary to have an understanding for policymakers about the concept of good tourism planning. In various cases in Indonesia, planning is critical as a guide in future development (Rizal et al., 2019; Rizal et al., 2020b). Without comprehensive planning, tourism development can be carried out sustainably (Wagner et al., 2011; Butler, 2015; Zenker and Kock, 2020). So far, development planning is still partially contained in each sub-activity sector. Sustainable tourism development is also adopted as the tourism development vision of each region (Rizal et al., 2019; Rizal et al., 2020a; Rizal et al., 2020b). However, in its development, formal and holistic regulations and indicators that can be adopted 
and used as guidelines in assessing development success are not entirely available. Sustainable tourism policies cannot be implemented concretely in the development of tourism in all regions in Indonesia.

\section{Government and Tourism Policy}

Tourism policy is generally seen as part of economic policy. The economic policy deals with the structure and growth of the economy, which is usually manifested in tourism planning. Some of the critical factors that concern economic policy include employment, investment, finance, industry, and trade (Panzabekova, 2018; Trip et al., 2021). Furthermore, Miller and Hadley (2005) and Wagner et al. (2011) explained that the formulation of tourism policies is an essential responsibility that governments must carry out to develop or maintain tourism as an integral part of the economy. The policy generally refers to an overall, high-level plan that includes objectives and procedures. For this reason, public policy considers the desired outcome of the government and the methods for achieving these results. Policies embody goals and strategies that the government has adopted concerning tourism, economic development, jobs, political relations, or a combination of the three. Therefore, the involvement of the public sector is critical in determining tourism policy.

According to Trip et al. (2021) states that the scope of the national tourism policy has become a promotional tool to attract tourist visits. All policies made are for efforts to improve the image of a tourist destination. In the last decade, cooperation and collaboration between government and private institutions have grown stronger. Tourism development policies need to be implemented by the private sector as well as the public sector. For this reason, the synergy between the government, entrepreneurs, and the community is needed in tourism planning and development (Panzabekova, 2018; Leposa, 2020; Aktymbayeva et al., 2020; Trip et al., 2021). The government, private sector, and society must have the option to do something constructive about tourism policy. The situation is an opportunity and, at the same time, an obligation to make, implement and maintain a well-made policy. The most important thing is coordination with the private sector and government to avoid concerns about public welfare (Butler, 2015). According to Zenker and Kock (2020), almost universally, governments globally accept tourism that has a positive impact, so that tourism policies are made to expand the tourism industry.

\section{Research Framework}

Pangandaran District has coastal tourism that can be developed to improve community welfare and regional income. The tourism potential is supported by various other sectors such as fisheries, transportation, hotels, ports, and the coastal industry. Given these supporters' potential, coastal tourism management must be carried out in an integrated manner (Integrated Coastal Tourism Management) by involving all relevant stakeholders. However, the reality shows that coastal tourism management in Pangandaran District tends to be carried out partially by relying on each agency's sectoral ego, which causes its management to be suboptimal and full of conflicts of interest, threatens the sustainability of coastal tourism itself. In the management of sustainable coastal tourism, it is mandated that the sectors contained therein can be optimally utilized for the community's welfare, both present and future generations. Measuring coastal tourism management's sustainability can be seen from three dimensions of sustainable development: ecological, economic, and social dimensions (Munasinghe, 1993; Molina-Azorín and Font, 2016). In connection with the previous, this study aims to analyze a sustainable coastal tourism management policy strategy (Figure 1), where the results of this study are expected to be used as consideration in the formulation of regional development policies in Pangandaran District.

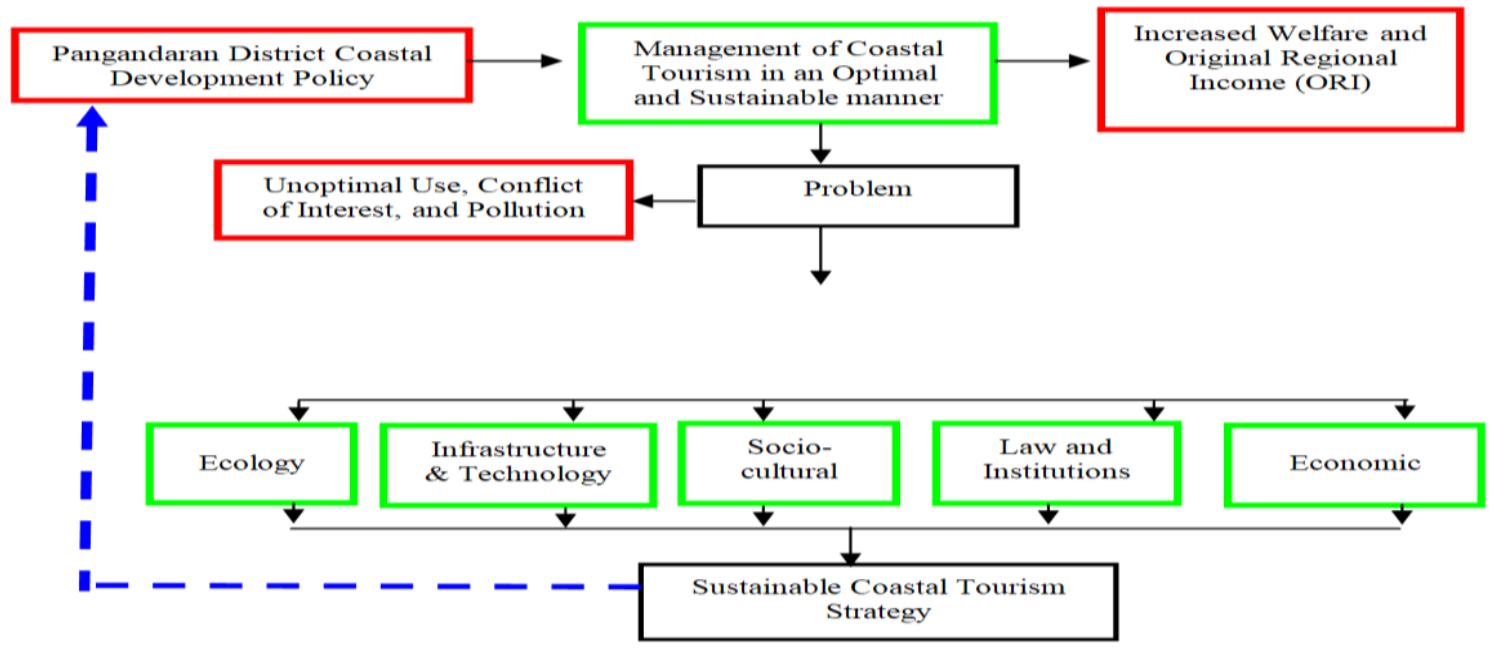

Figure 1. Research Framework

The research was conducted in the coastal Pangandaran District, six districts were designated as a purposive study from 10 districts, with considerations; (1) the geographical location of a sub-district close to or directly adjacent to the Pangandaran beach (2) the sub-district based on the determination of the Ministry of Marine Affairs and Fisheries (MMAF) to be included in the coastal sub-district in Pangandaran District (3) synergy with the development program that has been declared by the local government (4) land potential that allows for the development of coastal tourism and is supported by adequate public facilities and infrastructure. The research was conducted from January to March 2021. 


\section{METHOD OF ANALYSIS}

This sustainable development model will use a variety of analysis tools such as those described above by using resource mapping analysis, economic market and non-market valuation, social mapping, social perception analysis, Rap-CoastalDev (Rapid appraisal for Coastal development), adapted from the RAPFISH model for a fisheries sustainability analysis (Pitcher, 1999; Pitcher and Preikshot, 2001), efficiency analysis (data envelopment analysis), B/C non-conventional analysis using economic valuation (Pitcher et al., 2013). In this paper, the authors will focus only on readiness analysis and Rap-CoastalDev analysis (Rizal et al., 2020a). Rap-CoastalDev is RAP and MDS as a rapid multidisciplinary appraisal to evaluate comparative sustainability, based on many easy-to-score attributes. In this study, the Rap-CoastalDev application is developed to develop coastal tourism and analyze tourism development sustainability at the Pangandaran District (Figure 2). The Rap-CoastalDev analysis uses ecological, economic, socio-culture, infrastructure and technology, and institutional dimensions.

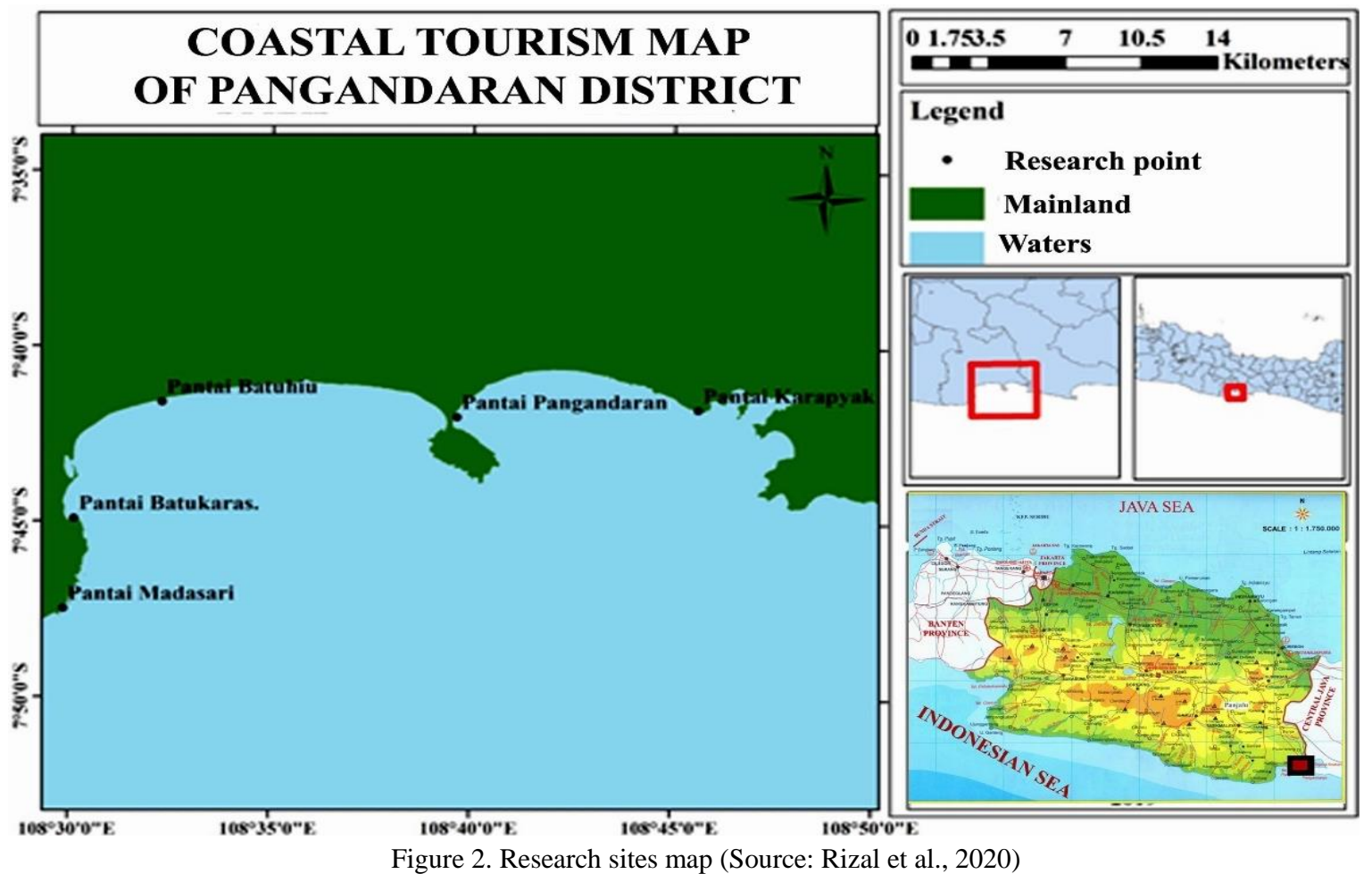

The prospective analysis is carried out to produce a sustainable coastal tourism development scenario in Pangandaran District by determining the key factors affecting system performance. The key factors were taken from the results of the Multidimensional Scaling (MDS) analysis of 18 critical factors as follows:

1. Ecological dimensions consist of critical factors: (1) Coastal water productivity, (2) intensity of coastal area conversion, (3) availability of information on agro-climate zones, and (4) Condition of the coastal environment.

2. Economic dimensions consist of critical factors: (5) Feasibility of local food processing industry, (6) Feasibility of the local souvenir industry, and (7) the contribution of the tourism sector to Gross Domestic Region Product (GDRP).

3. Socio-cultural dimensions consist of critical factors: (8) community empowerment in tourism activities, (9) the role of indigenous peoples in tourism activities, and (10) community relations patterns in tourism activities.

4. Infrastructure and technology dimensions consist of critical factors: (11) level of mastery of technology, (12) internet network availability, (13) use of online reservation technology, (14) support for road facilities and infrastructure, and (15) availability of tourism database.

5. Legal and institutional dimensions consist of critical factors: (16) cooperation agreements with private parties, (17) existence of microfinance institutions, and (18) cross-sectoral cooperation mechanisms in the development of coastal areas.

Table 1. Conditions that may occur in the future in the Development of Coastal Tourism in Pangandaran District

\begin{tabular}{|c|c|c|c|}
\hline \multirow{2}{*}{ FACTOR } & \multicolumn{3}{|c|}{ CONDITIONS AND } \\
& \multicolumn{2}{|c|}{ CIRCUMSTANCES } \\
\hline $\begin{array}{c}\text { FACTOR } \\
1\end{array}$ & $1 \mathrm{~A}$ & $1 \mathrm{~B}$ & $1 \mathrm{C}$ \\
\cline { 2 - 4 } & & & \\
\hline $\begin{array}{c}\text { FACTOR } \\
2\end{array}$ & $2 \mathrm{~A}$ & $2 \mathrm{~B}$ & $2 \mathrm{C}$ \\
\cline { 2 - 4 } $\begin{array}{c}\text { FACTOR } \\
3\end{array}$ & $3 \mathrm{~A}$ & $3 \mathrm{~B}$ & $3 \mathrm{C}$ \\
\cline { 2 - 4 } & & & \\
\hline $\begin{array}{c}\text { FACTOR } \\
\mathrm{n}\end{array}$ & $\mathrm{nA}$ & $\mathrm{nB}$ & $\mathrm{nC}$ \\
\cline { 2 - 4 } & & & \\
\hline
\end{tabular}

Table 2. The results of scenario analysis of sustainable coastal tourism development in Pangandaran District

\begin{tabular}{|l|l|l|}
\hline No & Scenario & Order Factor \\
\hline 1. & $\begin{array}{l}\text { Conservative-Pessimistic } \\
\text { (Enduring existing conditions }\end{array}$ & 1B, 2B, 3A, 4C, 5C, 6A, 7B, \\
& 8hile making improvised repairs) & 14B, 15A, 16B, 17C, 18C \\
\hline 2. & $\begin{array}{l}\text { Moderate-Optimistic } \\
\text { (make improvements but not }\end{array}$ & 1B, 2B, 3B, 4C, 5C, 6B, 7B, \\
& 8B, 9C, 10C, 11C, 12A, 13B, \\
maximal) & 14C, 15B, 16C, 17C, 18C \\
\hline 3. & Progressive-Optimistic & 1C, 2C, 3C, 4C, 5C, 6C, 7C, \\
& (make comprehensive and & 8B, 9C, 10C, 11C, 12C, 13C, \\
integrated repairs) & 14C, 15B, 16C, 17C, 18C \\
\hline
\end{tabular}


Based on the key factors that affect the system, a situation that may occur in the future from these factors is developed as an alternative to developing scenarios for coastal tourism in Pangandaran District. Table 1 presents conditions that may occur in the future and the dominant factors in coastal tourism development. Based on Table 1 above, a coastal tourism development scenario is built-in Pangandaran District. The scenarios that might occur in the future are as shown in Table 2.

\section{RESULTS DISCUSSIONS}

Pangandaran District coastal tourism development strategy for sustainable regional development is carried out using prospective analysis to predict the possibilities that will occur in the future according to the objectives to be achieved. The prospective analysis is carried out in three stages, namely (1) identifying critical factors in the future, (2) determining strategic goals and interests of the main actors, and (3) defining and describing the evolution of possibilities in the future as well as determining sustainable coastal tourism development strategies according to natural resources, which are owned. The critical factors in this analysis are determined by determining the key factors sensitive to the sustainability analysis results' system performance. Based on the sustainability analysis results, 18 sensitive factors (attributes) are obtained, as in Table 3.

The results of determining the key factors above then compiled the state (state) that may occur in the future. The state of each factor is presented in Table 4.
Table 3. Critical Influencing Factors in Coastal Tourism

Development Based on the Sustainability Analysis

\begin{tabular}{|c|l|}
\hline No & \multicolumn{1}{|c|}{ Sustainability Analysis Factors } \\
\hline 1. & Coastal water productivity \\
\hline 2. & The intensity of conversion of the coastal area \\
\hline 3. & Availability of agro-climate zone information \\
\hline 4. & Condition of the coastal environment \\
\hline 5. & Feasibility of local food processing industry \\
\hline 6. & Feasibility of the local souvenir industry \\
\hline 7. & The contribution of the tourism sector to GDRP \\
\hline 8. & Patterns of public relations in coastal tourism activities \\
\hline 9. & The role of indigenous peoples in coastal tourism activities \\
\hline 10. & Community empowerment in coastal tourism activities \\
\hline 11. & Level of mastery of technology \\
\hline 12. & Internet network availability \\
\hline 13. & Use of online reservation technology \\
\hline 14. & Support for road facilities and infrastructure \\
\hline 15. & Availability of tourism database \\
\hline 16. & Cooperation agreements with private parties \\
\hline 17. & Existence of microfinance institutions \\
\hline 18. & Cross-sectoral cooperation mechanisms in the development of coastal areas \\
\hline
\end{tabular}

Table 4. Conditions of Each Key Factor in the Development of Coastal Tourism in Pangandaran District

\begin{tabular}{|c|c|c|c|c|}
\hline \multirow{2}{*}{ No } & \multirow{2}{*}{ Factor } & \multicolumn{3}{|c|}{ Situation (State) } \\
\hline & & 1A & 1B & 1C \\
\hline \multirow{2}{*}{1} & Coastal water productivity & Bad & Still, as it is today (Moderate) & Good \\
\hline & & $2 \mathrm{~A}$ & 2B & $2 \mathrm{C}$ \\
\hline \multirow[t]{2}{*}{2} & $\begin{array}{l}\text { The intensity of conversion of the } \\
\text { coastal area }\end{array}$ & Uncontrolled rising (high) & Still, as it is today (Moderate) & $\begin{array}{l}\text { Decreasing due to land policy } \\
\text { (low) }\end{array}$ \\
\hline & & 3A & 3B & 3C \\
\hline \multirow[t]{2}{*}{3} & $\begin{array}{l}\text { Availability of agro-climate zone } \\
\text { information }\end{array}$ & $\begin{array}{c}\text { Still, as it is today (not } \\
\text { available) }\end{array}$ & $\begin{array}{l}\text { Available but only in certain } \\
\text { places }\end{array}$ & $\begin{array}{l}\text { Available in all places } \\
\text { accessible to tourists }\end{array}$ \\
\hline & & $\mathbf{4 A}$ & $4 \mathrm{~B}$ & $4 \mathrm{C}$ \\
\hline \multirow[t]{2}{*}{4} & $\begin{array}{c}\text { Condition of the coastal } \\
\text { environment }\end{array}$ & $\begin{array}{c}\text { Still, as it is today (not so } \\
\text { good) }\end{array}$ & $\begin{array}{l}\text { Improving the quality in } \\
\text { certain areas }\end{array}$ & Improve the quality in all areas \\
\hline & & $5 \mathbf{A}$ & $5 \mathbf{5 B}$ & $5 \mathrm{C}$ \\
\hline \multirow[t]{2}{*}{5} & $\begin{array}{l}\text { Feasibility of local food } \\
\text { processing industry }\end{array}$ & $\begin{array}{c}\text { Not feasible (not } \\
\text { economically profitable) }\end{array}$ & Moderate & $\begin{array}{l}\text { feasible (there was an } \\
\text { increase due to coaching) }\end{array}$ \\
\hline & & $6 \mathrm{~A}$ & 6B & $6 \mathrm{C}$ \\
\hline \multirow[t]{2}{*}{6} & $\begin{array}{c}\text { Feasibility of the local souvenir } \\
\text { industry }\end{array}$ & $\begin{array}{c}\text { Not feasible (not } \\
\text { economically profitable) }\end{array}$ & Moderate & $\begin{array}{l}\text { feasible (there was an } \\
\text { increase due to coaching) }\end{array}$ \\
\hline & & $7 \mathrm{~A}$ & 7B & $7 \mathrm{C}$ \\
\hline \multirow[t]{2}{*}{7} & $\begin{array}{l}\text { The contribution of the tourism } \\
\text { sector to GDRP }\end{array}$ & Still, as it is today (Low) & $\begin{array}{l}\text { There is an increase but not } \\
\text { optimal }\end{array}$ & $\begin{array}{l}\text { Increased sharply due to service } \\
\text { and technology improvements }\end{array}$ \\
\hline & & $\mathbf{8 A}$ & $\mathbf{8 B}$ & \\
\hline \multirow[t]{2}{*}{8} & $\begin{array}{l}\text { Patterns of public relations in } \\
\text { coastal tourism activities }\end{array}$ & $\begin{array}{l}\text { Not mutually beneficial } \\
\text { because it relies on the } \\
\text { relationship between them }\end{array}$ & $\begin{array}{l}\text { Mutual benefit because it } \\
\text { prioritizes group cooperation }\end{array}$ & \\
\hline & & 9A & 9 9B & $9 \mathrm{C}$ \\
\hline \multirow[t]{2}{*}{9} & $\begin{array}{l}\text { The role of indigenous peoples in } \\
\text { coastal tourism activities }\end{array}$ & It does not play a role & $\begin{array}{l}\text { Play a more dominant role } \\
\text { without being balanced with } \\
\text { existing rules and technology }\end{array}$ & $\begin{array}{l}\text { A role that is balanced with the } \\
\text { rules and the introduction of } \\
\text { technology }\end{array}$ \\
\hline & & 10A & $10 \mathrm{~B}$ & \\
\hline \multirow[t]{2}{*}{10} & $\begin{array}{l}\text { Community empowerment in } \\
\text { coastal tourism activities }\end{array}$ & $\begin{array}{l}\text { The community is not } \\
\text { empowered }\end{array}$ & $\begin{array}{l}\text { There is community } \\
\text { empowerment but only in } \\
\text { specific activities }\end{array}$ & $\begin{array}{l}\text { The community is always } \\
\text { empowered in every tourism } \\
\text { activity }\end{array}$ \\
\hline & & $11 \mathrm{~A}$ & $11 \mathrm{~B}$ & $11 \mathrm{C}$ \\
\hline 11 & level of mastery of technology & $\begin{array}{l}\text { there was a setback because } \\
\text { there was no transfer of } \\
\text { technology to the community }\end{array}$ & $\begin{array}{c}\text { there is mastery of technology, } \\
\text { but there is no improvement } \\
\text { and progress }\end{array}$ & $\begin{array}{l}\text { Improvement and mastery of } \\
\text { technology through the } \\
\text { introduction of new technology }\end{array}$ \\
\hline
\end{tabular}


Sustainable Management Policy Strategy of Coastal Tourism in Pangandaran District, Indonesia

\begin{tabular}{|c|c|c|c|c|}
\hline & & $12 \mathrm{~A}$ & 12B & $12 \mathrm{C}$ \\
\hline \multirow[t]{2}{*}{12} & Internet network availability & Not available & Moderate & Available \\
\hline & & $13 \mathrm{~A}$ & 13B & 13C \\
\hline \multirow[t]{2}{*}{13} & Use of online reservation technology & Basic & Medium & Modern \\
\hline & & $14 \mathrm{~A}$ & 14B & $14 \mathrm{C}$ \\
\hline \multirow[t]{2}{*}{14} & $\begin{array}{l}\text { Support for road facilities and } \\
\text { infrastructure }\end{array}$ & $\begin{array}{l}\text { Still, as it is today } \\
\text { (inadequate) }\end{array}$ & $\begin{array}{l}\text { There are improvements but } \\
\text { only in certain areas }\end{array}$ & $\begin{array}{l}\text { there has been an increase in all } \\
\text { road access (District, } \\
\text { Subdistrict, Village, tourism site) }\end{array}$ \\
\hline & & $15 \mathrm{~A}$ & 15B & $15 \mathrm{C}$ \\
\hline \multirow[t]{2}{*}{15} & Availability of tourism database & $\begin{array}{c}\text { Still, as it is today (Not } \\
\text { available) }\end{array}$ & Moderate & Available \\
\hline & & $16 \mathrm{~A}$ & $16 B$ & $16 \mathrm{C}$ \\
\hline \multirow[t]{2}{*}{16} & $\begin{array}{l}\text { cooperation agreements with } \\
\text { private parties }\end{array}$ & Not available & Available but not effective & Available and effective \\
\hline & & 17A & 17B & $17 \mathrm{C}$ \\
\hline \multirow[t]{2}{*}{17} & $\begin{array}{c}\text { existence of microfinance } \\
\text { institutions }\end{array}$ & Not available & Available but not effective & Available and effective \\
\hline & & 18A & $18 B$ & $18 \mathrm{C}$ \\
\hline 18 & $\begin{array}{c}\text { cross-sectoral cooperation } \\
\text { mechanisms in the development of } \\
\text { coastal areas }\end{array}$ & Not available & Available but not effective & $\begin{array}{c}\text { Available and running } \\
\text { effectively by involving related } \\
\text { agencies }\end{array}$ \\
\hline
\end{tabular}

Based on Table 4 above, some situations have little or no chance of occurring together (mutually incompatible). There is a line connecting one state to another, such as the productivity of coastal water decreasing gradually according to the high economic activities with the intensity of land conversion increasing uncontrollably (high). Likewise with other state relationships, but due to the key factors that are multi-scenario and displayed in several sheets so that the relationship that is not possible to occur together cannot be displayed on different sheets, but in scenario preparation, this relationship is still considered. From the various possibilities that occur as mentioned above, three groups of coastal tourism development scenarios in Pangandaran District can be formulated for the development of sustainable coastal areas that have a great chance of happening in the future, namely:

1. Conservative-pessimistic by making modest improvements to the key attributes (factors),

2. Moderate-Optimistic by making improvements about $50 \%$ of the critical attributes (factors),

Progressive-Optimistic by making improvements to all key attributes (factors). The scenarios that can be arranged are shown in Table 5. As in Table 5 above, the preparation of scenarios is based on the consideration of the government's ability as a facilitator in implementing a pilot coastal tourism development program and an allocation of program implementation time which is around five years, which is then submitted to the coastal tourism management agency. Thus, the implementation time allocation can be divided into short term, namely around 1-2 years ahead, medium-term around 35 years ahead, and long term, i.e., more than five years ahead. The following is a description of each scenario and the sustainability status that can be achieved for the future.

Table 5. Results of the Scenario Analysis of the Coastal Tourism Development Strategy for the Pangandaran District

\begin{tabular}{|c|c|c|}
\hline No. & $\begin{array}{l}\text { Strategy } \\
\text { Scenarios }\end{array}$ & Factor composition \\
\hline 0 & $\begin{array}{l}\text { Existing } \\
\text { conditions }\end{array}$ & $\begin{array}{l}1 \mathrm{~B}, 2 \mathrm{~A}, 3 \mathrm{~A}, 4 \mathrm{C}, 5 \mathrm{C} \\
6 \mathrm{~A}, 7 \mathrm{~A}, 8 \mathrm{~B}, 9 \mathrm{C}, 10 \mathrm{~A} \\
11 \mathrm{~B}, 12 \mathrm{~A}, 13 \mathrm{~A}, 14 \mathrm{C} \\
15 \mathrm{~A}, 16 \mathrm{~A}, 17 \mathrm{~A}, 18 \mathrm{C}\end{array}$ \\
\hline 1. & $\begin{array}{l}\text { Conservative } \\
\text {-pessimistic }\end{array}$ & $\begin{array}{l}1 \mathrm{~B}, 2 \mathrm{~B}, 3 \mathrm{~A}, 4 \mathrm{C}, 5 \mathrm{C} \\
6 \mathrm{~A}, 7 \mathrm{~B}, 8 \mathrm{~A}, 9 \mathrm{C}, 10 \mathrm{~B}, \\
11 \mathrm{~B}, 12 \mathrm{~A}, 13 \mathrm{~B}, 14 \mathrm{~B} \\
15 \mathrm{~A}, 16 \mathrm{~B}, 17 \mathrm{C}, 18 \mathrm{C}\end{array}$ \\
\hline 2. & $\begin{array}{l}\text { Moderate- } \\
\text { Optimistic }\end{array}$ & $\begin{array}{l}1 \mathrm{~B}, 2 \mathrm{~B}, 3 \mathrm{~B}, 4 \mathrm{C}, 5 \mathrm{C} \\
6 \mathrm{~B}, 7 \mathrm{~B}, 8 \mathrm{~B}, 9 \mathrm{C}, 10 \mathrm{C} \\
11 \mathrm{C}, 12 \mathrm{~A}, 13 \mathrm{~B}, 14 \mathrm{C} \\
15 \mathrm{~B}, 16 \mathrm{C}, 17 \mathrm{C}, 18 \mathrm{C}\end{array}$ \\
\hline 3. & $\begin{array}{l}\text { Progressive- } \\
\text { Optimistic }\end{array}$ & $\begin{array}{l}1 \mathrm{C}, 2 \mathrm{C}, 3 \mathrm{C}, 4 \mathrm{C}, 5 \mathrm{C} \\
6 \mathrm{~B}, 7 \mathrm{C}, 8 \mathrm{~B}, 9 \mathrm{C}, 10 \mathrm{C}, \\
11 \mathrm{C}, 12 \mathrm{C}, 13 \mathrm{C}, 14 \mathrm{C} \\
15 \mathrm{~B}, 16 \mathrm{C}, 17 \mathrm{C}, 18 \mathrm{C}\end{array}$ \\
\hline
\end{tabular}

Table 6. Changes in the Scoring Attribute Value that Affects Scenario1 on the Improvement of Coastal Tourism Status

\begin{tabular}{|c|l|c|c|}
\hline \multirow{2}{*}{$\mathrm{No}$} & \multicolumn{1}{|c|}{ Key Attribute } & \multicolumn{2}{c|}{ Scoring } \\
\cline { 2 - 4 } & & Existing & Scenario 1 \\
\hline 1 & Coastal water productivity & 2 & 2 \\
\hline 2 & The intensity of conversion of the coastal area & 0 & 1 \\
\hline 3 & Availability of agro-climate zone information & 0 & 0 \\
\hline 4 & Condition of the coastal environment & 2 & 2 \\
\hline 5 & Feasibility of local food processing industry & 2 & 2 \\
\hline 6 & Feasibility of the local souvenir industry & 0 & 0 \\
\hline 7 & The contribution of the tourism sector to GDRP & 1 & 1 \\
\hline 8 & Patterns of public relations in coastal tourism activities & 2 & 2 \\
\hline 9 & The role of indigenous peoples in coastal tourism activities & 0 & 1 \\
\hline 10 & Community empowerment in coastal tourism activities & 1 & 1 \\
\hline 11 & Level of mastery of technology & 1 & 1 \\
\hline 12 & Internet network availability & 0 & 1 \\
\hline 13 & Use of online reservation technology & 0 & 1 \\
\hline 14 & Support for road facilities and infrastructure & 0 & 0 \\
\hline 15 & Availability of tourism database & 0 & 1 \\
\hline 16 & Cooperation agreements with private parties & 2 & 2 \\
\hline 17 & Existence of microfinance institutions & 0 & 0 \\
\hline 18 & Cross-sectoral cooperation mechanisms in the development of coastal areas & & \\
\hline
\end{tabular}

Scenario 1. Conservative-pessimistic

As explained above, the sustainability status of coastal tourism for district development can be improved by improving 
the key factors (attributes) that affect the area's status. In this scenario, efforts are made to make modest improvements, or in other words, improvements made based on the efficiency of costs incurred can be minimized as much as possible. Some of the sought-after vital attributes can be improved, such as coastal water productivity, the intensity of fishery land conversion, Feasibility of the local food processing industry, Feasibility of the local souvenir industry, and tourism contribution sector to GDRP. There will be changes in the improved attribute scoring values with these key attribute improvements as in Table 6. Changes in the scoring values of several key attributes above, then conducted a Rap-CoastalDev analysis to see how much increase in the value of the coastal tourism sustainability index of Pangandaran District for district development. The amount of change in the index value is based on the Rap-CoastalDev analysis results, as in Table 7.

Table 7 above shows an increase in the value of the sustainability index for all dimensions. Most of the dimensions have an index value below 50\%, except for the economic dimensions, which are still above 50\%. However, if seen from the value of the sustainability index in all dimensions, it is generally at a less sustainable status. There is implies that the coastal tourism conditions of Pangandaran District have not fully supported sustainable development. It can be seen that when this strategy was chosen, increasing the index value through the improvement of several critical attributes had not been maximally implemented. Therefore, efforts to improve the key attributes need to be continued for the future. Of course, with strong policy support from the government in an integrated manner, both the central government, provincial governments, and district governments, so coastal tourism in Pangandaran District has an increased status to be sustainable (Rizal et al., 2019).

Table 7. Changes in Pangandaran District Coastal Tourism Sustainability Index Value Based on Scenario 1

\begin{tabular}{|c|c|c|c|c|}
\hline No. & $\begin{array}{c}\text { Sustainability } \\
\text { Dimensions }\end{array}$ & $\begin{array}{c}\text { Existing } \\
\text { Index Value }\end{array}$ & $\begin{array}{c}\text { Scenario } \\
\text { Index Value 1 }\end{array}$ & $\begin{array}{c}\text { the } \\
\text { difference }\end{array}$ \\
\hline 1. & Ecological & 47,13 & 50,94 & 3,80 \\
\hline 2. & Economic & 53,89 & 56,52 & 2,63 \\
\hline 3. & Socio-cultural & 34,82 & 44,25 & 9,43 \\
\hline 4. & $\begin{array}{c}\text { Infrastructure } \\
\text { and technology }\end{array}$ & 13,28 & 29,79 & 16,51 \\
\hline 5. & $\begin{array}{c}\text { Legal and } \\
\text { institutional }\end{array}$ & 45,06 & 47,05 & 1,99 \\
\hline
\end{tabular}

Table 9. Changes in Pangandaran District Coastal Tourism Sustainability Index Value Based on Scenario 2

\begin{tabular}{|c|c|c|c|c|}
\hline No. & $\begin{array}{c}\text { Sustainability } \\
\text { Dimensions }\end{array}$ & $\begin{array}{c}\text { Existing } \\
\text { Index Value }\end{array}$ & $\begin{array}{c}\text { Scenario } \\
\text { Index Value 2 }\end{array}$ & $\begin{array}{c}\text { the } \\
\text { difference }\end{array}$ \\
\hline 1. & Ecological & 47,13 & 58,15 & 11,02 \\
\hline 2. & Economic & 53,89 & 60,87 & 6,98 \\
\hline 3. & Socio-cultural & 34,82 & 52,53 & 17,71 \\
\hline 4. & $\begin{array}{c}\text { Infrastructure } \\
\text { and technology }\end{array}$ & 13,28 & 43,87 & 30,59 \\
\hline 5. & $\begin{array}{c}\text { Legal and } \\
\text { institutional }\end{array}$ & 45,06 & 48,43 & 3,37 \\
\hline
\end{tabular}

\section{Scenario 2. Moderate-Optimistic}

In contrast to scenario one, efforts to improve several critical attributes in scenario two comprise $50 \%$ of all critical attributes (sensitive attributes). This strategy is based on considering that coastal tourism should be carried out in stages while still considering the available cost capabilities. Based on these considerations, it will have implications for the achievement of coastal tourism development for district development faster, and it is not easy to realize, while several attributes need to be addressed more seriously, and as soon as possible they affect other attributes. For example, the provision of road facilities and infrastructure will seriously hamper access to tourism if it is not handled immediately. The key attributes that were improved are as shown in Table 8. The results of changes in the scoring values of several key attributes in table 8 above, then a Rap-CoastalDev analysis is carried out to see how much the increase in the value of the coastal tourism sustainability index of Pangandaran District for district development in each dimension. The amount of change in the index value is based on the Rap-CoastalDev analysis results, as in Table 9.

In table 9 above, it can be seen that all the dimensions have a sustainability index value above $50 \%$ or are already in a reasonably sustainable status, except in the infrastructure - Technology and Legal - Institutional dimensions. However, to achieve ideal conditions, efforts to increase this index's value can still be made by maximizing improvements to existing attributes - some of the attributes still have the opportunity to be improved. Some of those things are Community empowerment in coastal tourism activities and Coastal water productivity, increasing the level of mastery of technology, Support for road facilities and infrastructure, Internet network availability, increasing use of online reservation technology, availability of tourism databases, cooperation agreements with the private sector as well as cross-sectoral cooperation mechanisms in developing coastal tourism. The handling of these attributes can be carried out in scenario three by making comprehensive and integrated repairs. 


\section{Scenario 3. Progressive-Optimistic}

In scenario 3, improvements are made to all key attributes. With this repair, of course, it requires money and takes a long time. In this case, it can be done in three time periods, namely the short term, by making improvements to the urgent attributes to be handled, then the medium and long term by making improvements to the attributes that support coastal tourism development. This situation can be done with a strong commitment from the government as a facilitator in pioneering coastal tourism development. Some of the critical factors that can be improved are shown in Table 10.

Table 10. Changes in the Scoring Attribute Value that Affects Scenario 3 on the Improvement of Coastal Tourism Status

\begin{tabular}{|c|l|c|c|}
\hline \multirow{2}{*}{ No } & \multicolumn{1}{|c|}{ Key Attribute } & \multicolumn{2}{c|}{ Scoring } \\
\cline { 2 - 4 } & \multicolumn{1}{|c|}{ Existing } & Scenario 3 \\
\hline 1 & Coastal water productivity & 2 & 3 \\
\hline 2 & The intensity of conversion of the coastal area & 0 & 3 \\
\hline 3 & Availability of agro-climate zone information & 0 & 2 \\
\hline 4 & Condition of the coastal environment & 2 & 2 \\
\hline 5 & Feasibility of local food processing industry & 2 & 2 \\
\hline 6 & Feasibility of the local souvenir industry & 0 & 1 \\
\hline 7 & The contribution of the tourism sector to GDRP & 0 & 2 \\
\hline 8 & $\begin{array}{l}\text { Patterns of public relations in coastal tourism } \\
\text { activities }\end{array}$ & 1 & 1 \\
\hline 9 & $\begin{array}{l}\text { The role of indigenous peoples in coastal } \\
\text { tourism activities }\end{array}$ & 2 & 2 \\
\hline 10 & $\begin{array}{l}\text { Community empowerment in coastal tourism } \\
\text { activities }\end{array}$ & 0 & 3 \\
\hline 11 & Level of mastery of technology & 1 & 2 \\
\hline 12 & Internet network availability & 1 & 2 \\
\hline 13 & Use of online reservation technology & 0 & 2 \\
\hline 14 & Support for road facilities and infrastructure & 0 & 2 \\
\hline 15 & Availability of tourism database & 0 & 1 \\
\hline 16 & Cooperation agreements with private parties & 0 & 2 \\
\hline 17 & existence of microfinance institutions & 2 & 2 \\
\hline 18 & $\begin{array}{l}\text { Cross-sectoral cooperation mechanisms in } \\
\text { the development of coastal areas }\end{array}$ & 0 & 1 \\
\hline
\end{tabular}

The low value of the sustainability index in the socio-cultural dimension is because many socio-cultural dimensions have not been considered to be handled in this scenario. After all, these attributes are not sensitive to affect the development of coastal tourism. Therefore, to further strengthen coastal tourism development in Pangandaran District, handling insensitive attributes is difficult to deny. This circumstance can be seen from the sustainability index value, which only reached around $60 \%$, while improvements to sensitive attributes were handled optimally. The situation means that the sustainability index value of around $40 \%$ is an error factor for the attributes that are not considered in increasing the value of the sustainability index in each scenario, namely attributes that are not sensitive to influence.

\section{Sustainability Indicators Development of coastal tourism in Pangandaran District}

Judging from the multidimensional sustainability analysis results illustrates that the sustainable condition of coastal tourism in Pangandaran District is currently in a less sustainable status with a sustainability index value of $41.09 \%$. Sustainability index value, both in the ecological, economic, socio-cultural, infrastructure and technology, and legal and institutional dimensions. Attributes that need to be addressed are attributes sensitive to the value of the area's sustainability index, without neglecting the attributes with no or less sensitive effect based on the Leverage analysis results.

In the context of developing Pangandaran District coastal tourism for future development, benchmarks are needed to find out whether coastal tourism has increased or decreased its sustainability status from development activities carried out, including improvements to attributes in each dimension. One of the benchmarks commonly used in assessing the sustainability of coastal tourism in the future is to establish indicators for the sustainability of regional development. WCED (1987), IUCN, UNEP, and WWF (1990), CSD (2001), World Bank (2006), UN-General Assembly (2015), and UN-Water (2015) have determined sustainable development indicators, which are divided into four dimensions of sustainability, namely environmental, economic, social, and institutional. However, based on needs, in this study, the sustainability of coastal tourism is developed into five dimensions with dimensions and sustainability indicators (Rizal et al., 2020a).

Achievement of indicators that support the status improvement in the ecological dimension, in principle, can be achieved by making improvements to the attributes in the ecological dimension, especially those that are sensitive to the increase in the value of the sustainability index. These attributes include the increase in Coastal water productivity, The intensity of conversion of the coastal area, and the availability of information on the Agro-climate zone. To support the development of coastal tourism in Pangandaran District, the urgent matter to be addressed is maintaining or reducing the intensity of conversion of the coastal area. However, currently, the intensity of coastal land conversion is still relatively low due to its slow development in this district. On the other hand, what needs to be promoted is Coastal water productivity. 
This state is aimed at supporting the development of coastal tourism. The productivity of existing coastal water, both old and new, needs to be increased by improving new environmentally friendly technologies. By increasing the productivity of coastal water, it is expected that the productivity of fishing activities to support the tourism business can increase so that people's income will increase (Chaverri, 1989; Kuralbayev, 2016; Anna et al., 2017; Khan et al., 2020).

Sustainability indicators in the economic dimension can be achieved by improving the attributes of the economic dimension. Attributes that need to be addressed are improving the feasibility level of local food processing industry business, especially those that have a high price value in the market and increasing the Feasibility of the local food processing industry so that business profits in this sector can also increase and increase the number of workers working in the tourism sector (Rakhmatullayeva et al., 2015; Lemmetyinen, 2017; Lemmetyinen and Go, 2010; Leposa, 2020). From the economic aspect, the main objective of developing coastal tourism is how the community's welfare can increase. This state can be achieved by increasing profits from coastal business activities and other businesses conducted by local business actors. This increase in welfare is closely related to the existing workforce, both in number and quality (Cincin-Sain and Robert, 1998; Panzabekova, 2018; Thapa, 2019; Goliath-Ludic and Yekela, 2020). As coastal tourism, it should be dominated by local workers from the local area. For the existing workforce to feel at home working in the tourism sector, it is essential to note that the supporting facilities needed in business activities must be adequate, such as mastery of internet technology and online reservation technology, tourism database availability, and broader marketing.

In the socio-cultural dimension, the achievement of sustainability indicators in this dimension can be obtained through improving attributes such as increasing mutually beneficial public relations patterns in tourism activities, increasing the role of indigenous peoples in tourism activities, increasing the number of villages with residents working in the tourism sector (Lester and Weeden, 2004; Franks and Cleaver, 2007; Liggett et al., 2010; Lozano at al., 2015; Mamutova, 2020). Pangandaran district as a coastal district, villages in Pangandaran district must be characterized as supporting coastal tourism villages, especially in villages that function as hinterlands. The impact of the growth of tourism villages is an increase in the local workforce. Concerning labor, an essential factor that needs to be considered for the existing workforce is the level of education they have, where this level of education is one of the keys to the sustainability of the area in the socio-cultural dimension. The fact shows that the workforce in coastal tourism in Pangandaran District is still classified as low, both formal education, which is still below the average level of national education and non-formal education.

In the infrastructure and technology dimensions, the achievement of sustainability indicators in this dimension can be achieved by improving attributes such as mastery of internet technology, support for public facilities and infrastructure, support for road facilities and infrastructure, Internet network availability, and online reservation technology. In coastal tourism in Pangandaran District, public facilities and infrastructure are still classified as very minimal, such as education, health, and social facilities, including road facilities, village roads, and tourism business roads. Likewise, the supporting facilities and infrastructure for tourism business, such as online reservation technology availability, are minimal. On the other hand, the mastery of Internet network technology for existing coastal tourism workers is also low, and access to tourism information is also lacking. This condition will significantly affect the sustainability of coastal tourism in the future (Wunder, 2000; Marsh, 2012; Kuralbayev et al., 2016; Morgan, 2018; Mardiatno et al., 2020). Therefore, in developing coastal tourism in Pangandaran District, public and tourism business facilities and infrastructure need to be appropriately handled. Of course, all relevant stakeholders, especially the government, are needed as facilitators in developing coastal tourism.

Leverage analysis is carried out to see the sensitive attributes contributing to the sustainability index value of the legal and institutional dimensions. Based on the results of the Leverage analysis, three sensitive attributes are obtained, the value of the sustainability index of the legal and institutional dimensions, namely (1) cooperation agreements with the private sector, (2) mechanisms for cross-sectoral cooperation in the development and (3) the existence of microfinance institutions in the coastal tourism sector In the legal and institutional dimensions, the achievement of sustainability indicators in this dimension can be done through the provision of Microfinance Institutions (MFIs), as well as increasing cross-sectoral cooperation in developing coastal tourism and synchronizing central and regional policies. The policy for developing coastal tourism in Pangandaran District is very much needed to get this district out of the way of being left behind and isolated, considering that this district has great potential for development in the tourism sector (Muth'en and Muth'en, 2002; Mustaina, 2015; Rizal et al., 2020a).

These coastal tourism development programs need synchronization between national and regional policies by prioritizing local communities' interests. In other words, proposals for coastal tourism development programs must come from the grass root, namely the local community (bottom-up) and not from the central government (top-down), although support from the central government is needed. On the other hand, cross-sectoral cooperation is also very much needed and the role of each existing social institution.Sustainability change based on these indicators can be seen from two types of indicators (Pahl-Wostl et al., 2013; Lemmetyinen, 2017; Leposa, 2020; Aktymbayeva et al., 2020), namely (1) condition indicators, namely indicators that define system conditions relative to desired can be used to assess environmental conditions. This condition indicator characterizes the entire magnitude of a particular resource state from the ideal condition values during the simulation period and (2) trend indicators, measuring how the system changes over time. This indicator describes all the linear trends of a resource state during the starting period.

\section{CONCLUSION}

Based on the research location's existing conditions, the ecological dimension is considered less sustainable, the economic dimension, the socio-cultural dimension, and the legal and institutional dimensions are pretty sustainable. In contrast, the infrastructure and technology dimensions are not sustainable. 
In multidimensional terms, coastal tourism in Pangandaran District has a reasonably sustainable status with 18 sensitive attributes that increase the sustainability index's value. The attributes include four attributes in the ecological dimension, three attributes in the economic dimension, three attributes in the social and cultural dimensions, five attributes in the infrastructure and technology dimensions, and three attributes in the legal and institutional dimensions. To increase the status of future (long-term) sustainability, the scenario that needs to be done to increase the sustainability status of coastal tourism development in Pangandaran District is a Progressive-Optimistic scenario by making comprehensive improvements to all sensitive attributes so that all dimensions become sustainable for the development of coastal tourism. The sustainability of coastal tourism development follows two types: condition indicator and trend indicator that describe a linear trend from resource development to optimal limits.

\section{Acknowledgments}

The authors wish to thank Universitas Padjadjaran, which funded the study through an internal research grant year 2021.

\section{REFERENCES}

Aktymbayeva, B., Koshkimbayeva, U., Abisheva, Z., Tokbergenova, U., \& Tumazhanova, M. (2020). Tourism Industry Development and Governance: A Comparative Stage Review of Kazakhstan's Experience for The Years of Independence, 1991-2020. GeoJournal of Tourism and Geosites, 34(1), 69-76. https://doi.org/10.30892/gtg.34110-621

Anna, Z., Agus, A.H.S., Maulina, I., Rizal, A., \& Hindayani, P. (2017). Biological Parameters of Fish Stock Estimation in Cirata Reservoir (West Java, Indonesia): A Comparative Analysis of Bio-Economic Models. Biodiversitas, 18 (4), $1468-1474$. https://doi.org/10.13057/biodiv/d180423

Butler, R. (2015). The evolution of tourism and tourism research. Tourism Recreation Research, 40(1), 16-27. https://doi.org/10.1080/02508281.2015.1007632

Chaverri, R. (1989). Coastal Management: The Costa Rica Experience. Coastal Zone'87, 5273-5285, V, America Society of Civil Engineering, New York.

Cincin-Sain, B., \& Robert, W.B. (1998). Integrated Coastal and Ocean Management, Concepts and Practices, Island Press Washington, DC. Covello, California, 964.

Franks, T., \& Cleaver, F. (2007). Water governance and poverty: a framework for analysis. Progress in Development Studies. 7(4), $291-306$.

Goliath-Ludic, K., \& Yekela, S. (2020). Resident's Perception of the Environmental Impact of Tourism: A Case Study of the Bawa Community in Butterworth, South Africa. GeoJournal of Tourism and Geosites, 33(4spl), 1527-1531. https://doi.org/10.30892/gtg.334spl12-603

Khan, A.M.A., Nasution, A.M., Purba, N.P., Rizal, A., Zahidah., Hamdani, H., Dewanti, L.P., Junianto., Nurruhwati, I., Sahidin, A., Supriyadi, D., Herawati, H., Apriliani, I.M., Ridwan, M., Gray, T.S., Jiang, M., Arief, H., Mill, A.C., \& Polunin, N.V.C. (2020). Oceanographic characteristics at fish aggregating device sites for tuna pole-and-line fishery in eastern Indonesia. Fisheries Research, 225, 105471. https://doi.org/10.1016/j.fishres.2019.105471

Kuralbayev, A., Myrzaliev, B., \& Sevim, B. (2016). Organizational and economic problems in the management of the spiritual-Historical development of tourism in South Kazakhstan Region. International Review of Management and Marketing, 6(2). https://doi.org/10.35808/ersj/699

Lemmetyinen, A. (2017). Safe, secure, and sustainable: Attributes of a strong cruise brand. In R. Dowling, \& C. Weeden (Eds.), Cruise ship tourism, 2nd ed., pp. 261-274, Oxfordshire: CABI.

Lemmetyinen, A., \& Go, F.M. (2010). Building a brand identity in a network of cruise Baltic's destinations - a multi-authoring approach. Journal of Brand Management, 17 (7), 519-531. https://doi.org/10.1057/bm.2010.5

Leposa, N. (2020). Problematic blue growth: A thematic synthesis of social sustainability problems related to growth in the marine and coastal tourism. Sustainability Science, 15, 1233-1244. https://doi.org/10.1007/s11625-020-00796-9

Lester, J.A., \& Weeden, C. (2004). Stakeholders, the natural environment, and the future of Caribbean cruise tourism. International Journal of Tourism Research, 6(1), 39-50. https://doi.org/10.1002/jtr.471

Liggett, D., McIntosh, A., Thompson, A., Storey, B., \& Gilbert, N. (2010). Stakeholder perspectives on the governance of Antarctic cruise tourism. In M. Lück, P. T. Maher, \& E. J. Stewart (Eds.), Cruise tourism in polar regions. Promoting environmental and social sustainability? (pp. 167-180). London: Earthscan from Routledge.

Lozano, R., Carpenter, A., \& Huisingh, D. (2015). A review of 'theories of the firm' and their contributions to corporate sustainability. Journal of Cleaner Production, 106, 430-442. https://doi.org/10.1016/j.jclepro.2014.05.007

Mamutova, K. (2020). Destination Management Approach for Sustainable Tourism Development in Kazakhstan. Eurasian Journal of Economic and Business Studies, 2(56). https://doi.org/10.47703/ejebs.v2i56.15

Mardiatno, D., Malawani, M.N., \& Nisaa, R.M. (2020). The future tsunami risk potential as a consequence of building development in Pangandaran Region, West Java, Indonesia. International Journal of Disaster Risk Reduction, 46, 101523. https://doi.org/10.1016/j.ijdrr.2020.101523

Marsh, E. (2012). The effects of cruise ship tourism in coastal heritage cities. Journal of Cultural Heritage Management and Sustainable Development, 2(2), 190-199. https://dx.doi.org/10.2139/ssrn.2187653

Miller, M.L., \& Hadley N.P. (2005). Tourism and Coastal Development. In: Schwartz M.L. (eds) Encyclopedia of Coastal Science. Encyclopedia of Earth Science Series. Springer, Dordrecht. https://doi.org/10.1007/1-4020-3880-1_328

Miller, M.L., \& Ditton, R. (1986). Travel, tourism, and marine affairs. Coastal Zone Management Journal, 14(1/2): 1-19. https://doi.org/10.1080/08920758609361992

Molina-Azorín, J.F., \& Font, X. (2016). Mixed methods is sustainable tourism research: An analysis on prevalence, deigns and application in JOST (2005-2014). Journal of Sustainable Tourism, 24(4), 549-573. https://doi.org/10.1080/09669582.2015.1073739

Moreno, A., \& Amelung, B. (2009). Climate change and coastal \& marine tourism: Review and analysis. Journal of Coastal Research, 56, 1140-1144. https://doi.org/10.1080/08920750903054997

Morgan, D.L. (2018). Living within blurry boundaries: The value of distinguishing between qualitative and quantitative research. Journal of Mixed Methods Research, 12 (3), 268-279. https://doi.org/10.1177\%2F1558689816686433

Mostafa, G., \& Mahmood, M. (2018). Eurasian Economic Union: Evolution, challenges, and possible future directions. Journal of Eurasian Studies, 9 (2), 163-172. https://doi.org/10.1016/j.euras.2018.05.001 
Munasinghe, M. (1993). Environmental Economics and Sustainable Development. The International Bank for Reconstruction and Development/THE WORD BANK. Washington D.C. 20433. The U.S.A.

Mustaina, M., Armonoa, H.D., \& Kurniawan, D.T. (2015). The Evaluation of Beach Recreational Index for Coastal Tourism Zone of: Delegan, Kenjeran, and Wisata Bahari Lamongan. Procedia Earth and Planetary Science, 14, 17-24. https://doi.org/10.1016/j.proeps.2015.07.080

Muth'en, L.K., \& Muth'en, B.O. (2002). How to use a Monte Carlo study to decide on sample size and determine power. Structural Equation Modeling, 9(4), 599-620. https://doi.org/10.1207/S15328007SEM0904_8

Pahl-Wostl, C., Conca, K., Kramer, A., Maestu, J., \& Schmidt, F. (2013). Missing links in global water governance: a processes-oriented analysis. Ecology and Society. 18(2), 122-130. http://dx.doi.org/10.5751/ES-05554-180233

Palmer, M.A. (2012). Socioenvironmental sustainability and actionable science. BioScience. 62(1), 5-12. https://doi.org/10.1525/bio.2012.62.1.2

Panzabekova, A.Z. (2018). Diversification of tourism and economic development of Kazakhstan. R-Economy. 4(3), 82-87. https://doi.org/10.15826/recon.2018.4.3.012

Permana, R., Rizal, A., \& Hasan, Z. (2020). Plastic Consumption in Group of Teens and Young Adults from Pangandaran District, Indonesia: A Glimpse of Environmental Awareness among the Locals outside Big Cities, Asian Journal of Advanced Research and Reports, 12 (2), 1-9. https://doi.org/10.9734/ajarr/2020/v12i230282

Pitcher, T.J., \& Preikshot, D. (2001). RAPFISH: a rapid appraisal technique to evaluate the sustainability status of fisheries, Fisheries Resource., 49, 255-270. https://doi.org/10.1016/S0165-7836(00)00205-8

Pitcher, T.J. (1999). Raffish, A rapid appraisal technique for fisheries, and its application to the code of conduct for responsible fisheries, FAO Fisheries Circular, 947, 47.

Pitcher, T.J., Lam, M.E., Ainsworth, C., Martindale, A., Nakamura, K., Perry, R.I., \& Ward, T., (2013). Improvements to Rapfish: a rapid evaluation technique for fisheries integrating ecological and human dimensions. Journal of Fish Biology, 83, 865-889. https://doi.org/10.1111/jfb.12122

Rakhmatullayeva, D.Z., Bobkov, V.N., \& Zhatkanbayev, E.B. (2015). Modeling of Social Effect of Foreign Direct Investment in the Regions of Kazakhstan. R-Economy. 1(2), 325-339. https://doi.org/10.17059/2015-2-23

Rizal, A., Subiyanto., Juahir, H., \& Lananan, F. (2019). Freshwater Governance on Limboto Lake in Gorontalo Province of Indonesia. Indian Journal of Public Health Research \& Development, 10 (4), 782-787. https://dx.doi.org/10.5958/0976-5506.2019.00798.8

Rizal, A., Apriliani, I.M., \& Permana, R. (2020 a). Sustainability assessment of coastal development in the southern region of west java province, Indonesia. GeoJournal of Tourism and Geosites, 30(2spl), 808-817. https://doi.org/10.30892/gtg.302spl05-509 .

Rizal, A., Apriliani, I.M., Permana, R., \& Nurruhwati, I. (2020 b). Development and Coastal Environment Change, Will Have A Meeting Point? Case Study of Coastal Zone of West Java Province, Indonesia. GeoJournal of Tourism and Geosites, 31(3), 1034-1042. https://doi.org/10.30892/gtg.31315-538

Thapa, B. (2019). Ecotourism education and development in Kazakhstan. Journal of Hospitality \& Tourism Education, 31(2), $119-124$. https://doi.org/10.1080/10963758.2018.1485499

Trip, D.T., Fagadar, C.F., Badulescu, D., \& Badulescu, A. (2021). Entrepreneurship and Tourism Through the Lens of Sustainability. Charting the Knowledge Base Through Bibliometric Analysis. GeoJournal of Tourism and Geosites, 34(1), 140-146. https://doi.org/10.30892/gtg.34118-629

Wagner, M.E., Alves, H., \& Raposo, M. (2011). Stakeholder theory: Issues to resolve. Management Decision, 49(2), $226-252$. https://doi.org/10.1108/00251741111109133

Wunder, S. (2000). Ecotourism and economic incentives-an empirical approach. Ecological economics, 32(3), $465-479$. https://doi.org/10.1016/S0921-8009(99)00119-6

Zenker, S., \& Kock, F. (2020). The coronavirus pandemic-a critical discussion of a tourism research agenda. Tourism Management, 81, 104164. https://doi.org/10.1016/j.tourman.2020.104164

*** Commission on Sustainable Development [CSD]. (2001). Indicator of Sustainable Development; Framework and Methodology. Commission on Sustainable Development. Background Paper No.3. New York; Division for Sustainable Development.

*** UN - General Assembly. (2015). Transforming Our World. The 2030 Agenda for Sustainable Development. A/RES/70/1, United Nation.

*** UN - Water. (2015). Water for a sustainable world. The United Nations World Water Development Report. https://doi.org/10. 1016/S1366-7017(02)00004-1

*** UN - WTO. (2005). Making Tourism More Sustainable - A Guide for Policy Makers, United Nation.

*** World Bank. (2006). Poverty and social impact analysis of reform: Lessons and Examples from Implementation, The World Bank, 1818 H Street NW, Washington, DC. https://doi.org/10.1596/978-0-8213-6486-4

*** World Commission on Environment and Development (WCED). (1987). Our Common Future ("The Brundtland Report"). New York: Oxford University Press.

*** World Conservation Union (IUCN), the United Nations Environment Programme (UNEP), and the World-Wide Fund for Nature (WWF). (1990). Caring for the World: A Strategy for Sustainability. (Second Draft). Gland: IUCN.

\footnotetext{
Article history: Received: 25.03.2021 Revised: 08.06.2021 Accepted: 30.08.2021 Available online: 20.09.2021
} 